J. Perinat. Med. 9 (1981) 134
The influence of cord complications on fetal pH, neonatal APGAR score, and the acid base state and oxygenation of the umbilical artery and vein

\section{T. Weber}

Dept. of Obstetrics and Gynaecology, YA, Rigshospitalet, University of Copenhagen, Denmark
It has recently been suggested that umbilical cord complications play an important role in perinatal mortality and morbidity $[2,5]$ and that cord complications result in a decreased fetal blood $\mathrm{pH}$ and an increased difference between umbilical artery and vein blood $\mathrm{pH}[12]$.

In one of these papers [2] no control group without cord complications was used; in the other paper only cases with innocuous cardiotocographic patterns (CTG) were included in the control group [12].

Although cord prolapse is a very dangerous situation if delivery is not terminated at once [1], this situation only occurs in 0.43 per cent of all deliveries [4] and the effect of all other types of cord complications per se still remains to be investigated.

As 152 patients in our department were monitored with continuous scalp tissue $\mathrm{pH}(\mathrm{tpH})$ during labour followed by determination of the oxygenation and acid base state of both umbilical artery and vein, and as the position of the umbilical cord was noted in 142 of these patients, we have had the opportunity of investigating the effect of cord complications per se on all the above mentioned values and on the APGAR score.

\section{Material and method}

During labour 152 fetuses were continuously monitored with CTG and tpH. Tissue $\mathrm{pH}$ was measured by a glass electrode (RochE ${ }^{\circledR}$ ) and a pH meter (PHM73, RADIOMETER, Copenhagen) connected to a cardiograph (8030A, HEwLET PACKARD) both registrating tpH and CTG [13]. Tissue $\mathrm{pH}$ was not known to the obstetrician in charge of the patient. At the delivery the position of the umbilical cord was noted in 142 of 152 fetuses (all vertex presentations). In case of an abnormal position of the umbilical cord it was described as 1) beside the head, 2) around the neck, 3) around the trunk/shoulder(s), or 4) around one of the extremities. Furthermore, it was noted if there was more than one cord complication (e.g. around neck and trunk, twice around the neck), if the cord was tight or loose, if the cord was short (less than $40 \mathrm{~cm}$ ), and if there were any knots on the cord.

All cases with cord complications were compared to cases with no such complications. The following values were tested for differences between the two groups: $\mathrm{tpH}$ at $5,10,15,20,25,30,60,90$, and 120 minutes before delivery (only in the cases in which a good quality $\mathrm{pH}$ recording was obtained [14]); neonatal APGAR score one and five minutes after delivery (all cases); and $\mathrm{pH}, \mathrm{pCO}_{2}$, base excess, standard bicoarbonate, $\mathrm{pO}_{2}$, and oxygen saturation of the umbilical artery and vein (all cases except four in which a blood sample from the umbilical vessels could not be obtained). Furthermore, the few cases with tight cord loop(s), short cord, and a knot on the cord was described separ- 
ately, but included in the group of "cord complications".

No classification of the CTG was performed as the goal of this investigation was to study the influence of cord complications per se on the state of the fetus and newborn. Furthermore, several investigations have already shown a correlation between cord complications and variable decelerations of the fetal heart rate $[6,7,8,9,11,12]$.

\section{Statistics}

APGAR scores 0-7 versus 8-10 were compared between the two groups by the exact test of FisCHER.

All other values were compared between the two groups by a t-test. If the $p$ value (two-tailed) was less than 0.10 a MANN-WHITNEY $U$ test was also performed. The $\mathrm{p}$ values is mentioned only if a MANN-Whitney U test was performed.

The few cases of tight cord loop(s) are mentioned in a separate Table, but no statistical comparisons to other cases with/without cord complicaton(s) were performed because of the small number.

\section{Results}

Of the 142 deliveries, 45 ( 32 per cent) showed one or more cord complication(s) (Tab. I). Most of the complications were "cord around the neck" ( $28=20 \%$ of the total material), only five (4\%) having more than one complication, and only four
(3\%) having what was described as "tight loop(s)". There were two cases of short umbilical cord (35 and $37 \mathrm{~cm}$ ), one without other cord complications, the other in connexion with a loose cord around the neck. One case with a loose umbilical knot was connected with loose cord loops around the neck. There were no cases of prolapsed umbilical cord.

The 45 fetuses with cord complication(s) were delivered without intervention (58\%), by low forceps/vacuum extraction (22\% because of suspected fetal distress $-11 \%$ for other reasons), or by Caesarean section (7\% because of suspected fetal distress $-4 \%$ for other reasons).

The 97 fetuses without cord complication showed the following rates of intervention: Low forceps/ vacuum extraction: $10 \%$ because of suspected fetal distress, $10 \%$ for other reasons; Caesarean section: $4 \%$ because of suspected fetal distress, $5 \%$ for other reasons.

Fig. 1 illustrates the tpH during labor in cases with and without cord complications. There was no statistical difference between tpH in the two groups at any of the time periods. There were four cases in which a tight loop was noted at delivery. Two of those cases had a normal tpH until 60 minutes before delivery but during the last hour of labor tpH decreased to between 7.15 and 7.20; only one of the neonates had also low $\mathrm{pH}$ values in the umbilical vessels. The other two cases of tight cord loop(s) did not have a good quality tissue $\mathrm{pH}$ recording.

The neonatal APǴAR scores one and five minutes after delivery appears from Tab. II. There were no

Tab. I. Distribution of cord complications among the 142/152 deliveries in which the cord position was stated.

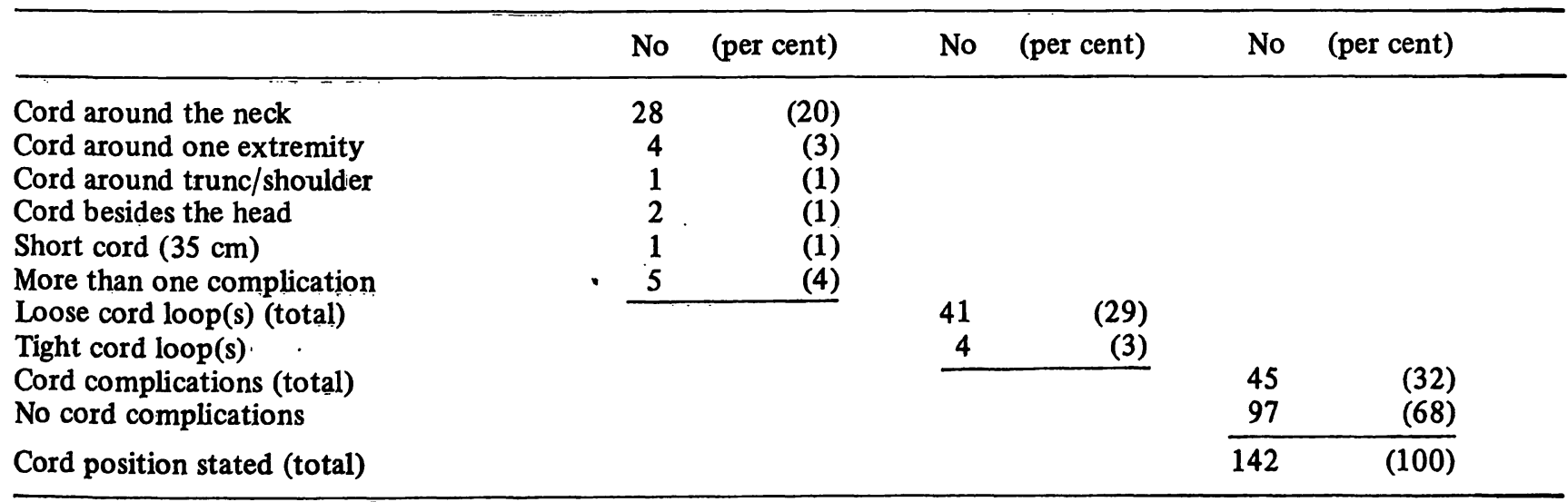




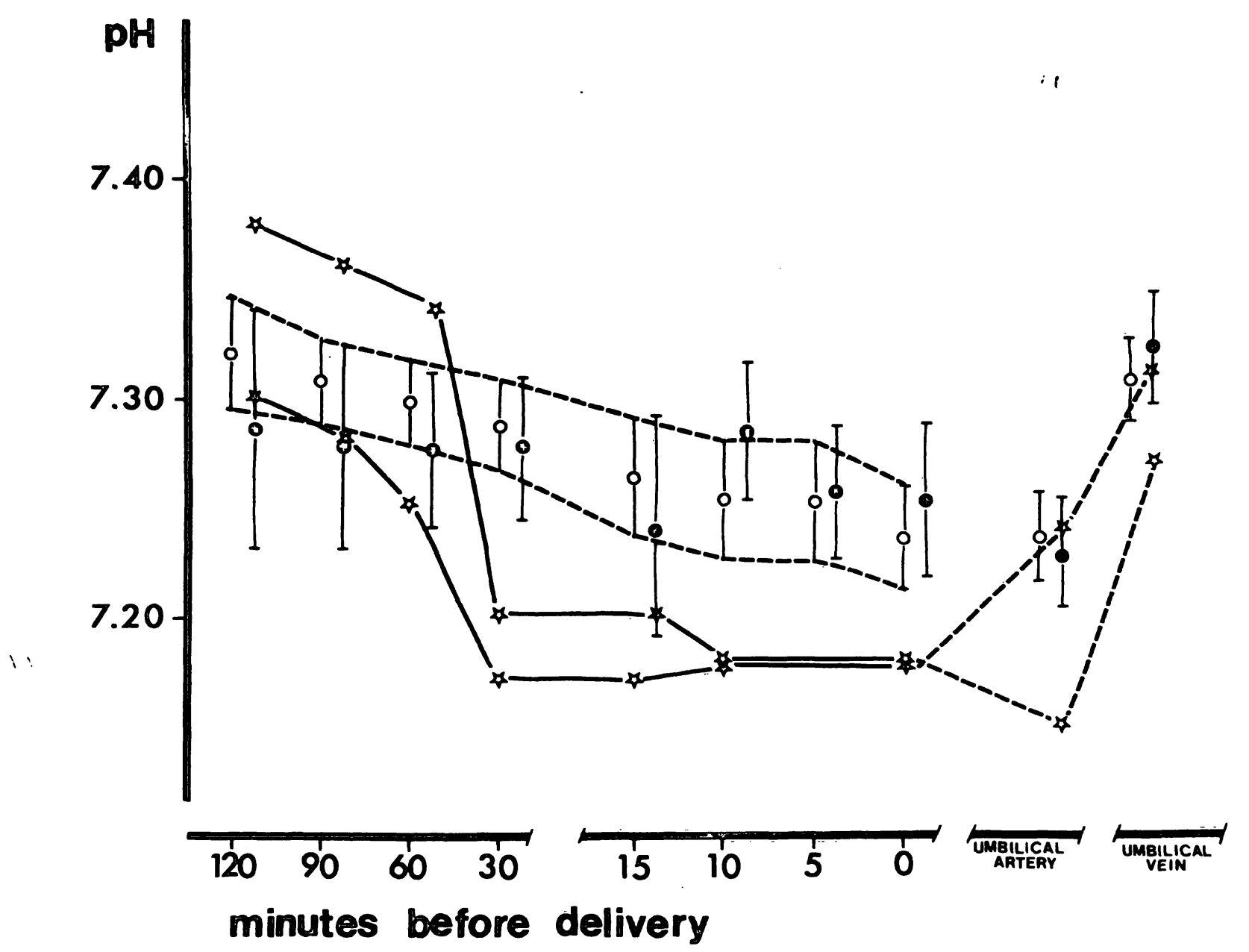

Fig. 1. Tissue pH during labour in fetuses with and without cord complications. $\circ$ : No cord complications (Mean \pm 2 SEM); $\bullet$ : All cord complications (Mean \pm 2 SEM); $\star$ : Two cases of tight cord loop(s). The number of observations at each time interval (cord complications in brackets) was: 120 minutes: 40 (11), 90 minutes: 45 (16), 60 minutes: 48 (20), 30 minutes: 55 (26), 15 minutes: 35 (15), 10 minutes: 36 (19), 5 minutes: 40 (17), 0 minutes: 52 (24).

statistical differences between APGAR scores of 0-7 versus $8-10$ in the two groups one and five minutes after delivery. The four neonates born with tight loop(s) all had APGAR scores of 8-10 one and five minutes after delivery.

The acid base and oxygenation state of the blood of the umbilical vessels appears from Tab. III. There was a slightly higher $\mathrm{A}-\mathrm{V}$ difference of the $\mathrm{pCO}_{2}$ in the group with cord complications (both tight and loose cord complications) compared to the group without cord complications $(\mathrm{p}=0.04)$. All the other tested values were equal in the two groups.

The same values in the umbilical vessels of the three neonates born with tight loop(s) appears from Tab. IV. In the umbilical artery both respiratory and metabolic components of the $\mathrm{pH}$ are lower than in the groups seen in Tab. III but the
$\mathrm{pO}_{2}$ is slightly higher whereas the oxygen saturation is lower. In the umbilical vein only the metabolic part of the $\mathrm{pH}$ is lower, the $\mathrm{pO}_{2}$ is about the same, and the oxygenation saturation is lower than in the groups of Tab. III. The $\mathrm{A}-\mathrm{V}$ difference is higher for all acid base values but lower for the $\mathrm{pO}_{2}$ and oxygen saturation when compared to the groups of Tab. III.

The cases with short umbilical cord and the case with a loose knot did not differ from the group without cord complications in respect to APGAR scores, tpH, and the acid base state and oxygenation of the umbilical vessels.

One of the neonates died because of cardiac incompensation after a normal delivery without cord complications. The other children were discharged from the hospital without evidence of neurological damage. 
Tab. Il. APG AR score one (APGAR $1^{\prime}$ ) and five (APGAR $5^{\prime}$ ) minutes after delivery according to the position of the umbilical cord.

\begin{tabular}{|c|c|c|c|c|c|c|}
\hline & \multicolumn{3}{|c|}{ APGAR I' } & \multicolumn{3}{|c|}{ APGAR $5^{\prime}$} \\
\hline & $\begin{array}{l}- \text { c.c.c. }^{2} \\
\text { No }\end{array}$ & $\begin{array}{l}+ \text { c.c.b } \\
\text { No }\end{array}$ & $\begin{array}{l}+ \text { t.l.ce } \\
\text { No }\end{array}$ & $\begin{array}{l}- \text { c.c.a } \\
\text { No }\end{array}$ & $\begin{array}{l}+ \text { c.c.b } \\
\text { No }\end{array}$ & $\begin{array}{l}+ \text { t.l.c } \\
\text { No }\end{array}$ \\
\hline $\begin{array}{c}10 \\
9 \\
8 \\
7 \\
6 \\
5 \\
4 \\
3 \\
2 \\
0-1\end{array}$ & $\begin{array}{r}10 \\
20 \\
9 \\
1 \\
1 \\
0 \\
2 \\
0 \\
1 \\
0\end{array}$ & $\begin{array}{r}44 \\
31 \\
10 \\
10 \\
0 \\
1 \\
1 \\
0 \\
1 \\
0\end{array}$ & $\begin{array}{l}0 \\
2 \\
2 \\
0 \\
0 \\
0 \\
0 \\
0 \\
0 \\
0\end{array}$ & $\begin{array}{r}38 \\
5 \\
0 \\
0 \\
0 \\
0 \\
1 \\
0 \\
0 \\
0\end{array}$ & $\begin{array}{r}89 \\
6 \\
3 \\
0 \\
0 \\
0 \\
0 \\
0 \\
0 \\
0\end{array}$ & $\begin{array}{l}3 \\
1 \\
0 \\
0 \\
0 \\
0 \\
0 \\
0 \\
0 \\
0\end{array}$ \\
\hline $0-7 / 8-10$ & $5 / 39 d$ & $13 / 85^{d}$ & $(0 / 4)$ & $1 / 43^{e}$ & $0 / 98^{e}$ & $(0 / 4)$ \\
\hline
\end{tabular}

a): No cord complication.

b): All cord complications.

c): Cord complication with tight loop(s), only.

d): $p=0.49$.

e): $\mathbf{p}=0.31$.

Tab. III. The acid base state and the oxygenation state in the umbilical vessels of neonates born after cord complication(s) (+ c.c.) and after no cord complication ( - c.c.).

\begin{tabular}{|c|c|c|c|c|c|c|}
\hline & \multicolumn{2}{|c|}{ Umbilical artery } & \multicolumn{2}{|l|}{ Umbilical vein } & \multicolumn{2}{|c|}{$\begin{array}{l}\text { Umbilical vein - } \\
\text { Umbilical artery }\end{array}$} \\
\hline & + c.c. & - c.c. & + c.c. & - c.c. & + c.c. & - c.c. \\
\hline $\begin{array}{l}\text { pH (units) } \\
\quad \text { (Mean } \pm 2 \text { SEM) }\end{array}$ & $7.23 \pm 0.02$ & $7.24 \pm 0.02$ & $7.32 \pm 0.03$ & $7.31 \pm 0.02$ & $0.09 \pm 0.02$ & $0.08 \pm 0.01$ \\
\hline $\begin{array}{l}\mathrm{pCO}_{2}(\mathrm{kPa}) \\
\quad(\text { Mean } \pm 2 \mathrm{SEM})\end{array}$ & $7.4 \pm 0.3$ & $7.1 \pm 0.3$ & $5.6 \pm 0.3$ & $5.5 \pm 0.2$ & $-1.8 \pm 0.2^{\mathrm{a}}$ & $-1.5 \pm 0.1^{\mathrm{a}}$ \\
\hline $\begin{array}{r}\text { Base excess }(\mathrm{meg} / 1) \\
(\text { Mean } \pm 2 \text { SEM })\end{array}$ & $-5.6 \pm 1.2$ & $-6.4 \pm 0.8$ & $-4.7 \pm 1.2$ & $-5.6 \pm 0.7$ & $1.4 \pm 0.6$ & $1.3 \pm 0.4$ \\
\hline $\begin{array}{l}\text { Standard bicarbonate } \\
\quad(\text { meq } / 1)(\text { Mean } \pm 2 \text { SEM })\end{array}$ & $18.1 \pm 0.9$ & $17.7 \pm 0.7$ & $19.6 \pm 1.0$ & $19.0 \pm 0.6$ & $1.6 \pm 0.5$ & $1.3 \pm 0.3$ \\
\hline $\begin{array}{l}\mathrm{pO}_{2}(\mathrm{kPa}) \\
\quad(\mathrm{Mean} \pm 2 \mathrm{SEM})\end{array}$ & $2.5 \pm 0.2$ & $2.8 \pm 0.3$ & $4.0 \pm 0.3$ & $4.0 \pm 0.3$ & $1.4 \pm 0.2$ & $1.2 \pm 0.1$ \\
\hline $\begin{array}{l}\text { Oxygen saturation } \\
\quad \text { (per cent) }(\text { Mean } \pm 2 \text { SEN }\end{array}$ & M) $28 \pm 6$ & $26 \pm 5$ & $53 \pm 7$ & $55 \pm 4$ & $32 \pm 6$ & $29 \pm 4$ \\
\hline
\end{tabular}

a): MANN-WHITNEY $U$ test: $p=0.04$ (two-tailed) (cord complication versus no cord complication).

J. Perinat. Med. 3 (1981) 
Tab. IV. The acid base state and the oxygenation state in the umbilical vessels of three neonates born after cord complication with a tight cord loopa.

\begin{tabular}{lccc}
\hline & Umbilical artery & Umbilical vein & $\begin{array}{c}\text { Umbilical vein - } \\
\text { artery }\end{array}$ \\
\hline $\mathrm{pH}$ (units) (Mean $\pm 2 \mathrm{SEM})$ & $7.14 \pm 0.12$ & $7.28 \pm 0.04$ & $0.13 \pm 0.08$ \\
$\mathrm{pCO}_{2}(\mathrm{kPa})(\mathrm{Mean} \pm 2 \mathrm{SEM})$ & $8.3 \pm 1.2$ & $5.6 \pm 1.0$ & $-2.7 \pm 0.6$ \\
Base excess (meq/l) (Mean $\pm 2 \mathrm{SEM})$ & $-9.4 \pm 6.4$ & $-7.4 \pm 4.1$ & $2.4 \pm 3.4$ \\
Standard bicarbonate (meq/l) (Mean $\pm 2 \mathrm{SEM})$ & $15.5 \pm 4.8$ & $17.3 \pm 3.1$ & $1.8 \pm 2.6$ \\
$\mathrm{pO}_{2}(\mathrm{kPa})$ (Mean \pm 2SEM) & $2.9 \pm 0.3$ & $3.8 \pm 0.3$ & $0.9 \pm 0.2$ \\
Oxygen saturation (per cent) (Mean $\pm 2 \mathrm{SEM}) \mathrm{b}$ & $18 \pm 15$ & $43 \pm 14$ & $25 \pm 1$ \\
\hline
\end{tabular}

a): After delivery of the fourth infant with a tight cord loop no blood was obtained from the umbilical vessels for analysis. No statistical analysis, because of the small number.

b): Only two infants with a tight loop had their umbilical blood analyzed for oxygen saturation.

\section{Discussion}

Cord complications may cause compression of the umbilical cord with compression of the umbilical vein and at higher pressures also the umbilical arteries. Consequently, a slight compression only influences the blood flow from the placenta to the fetus with subsequent lowering of the oxygen supply to the fetus through the umbilical vein. As the fetus tries to compensate the diminished blood flow by extracting more oxygen from the blood this situation may be detected by a lower $\mathrm{pO}_{2}$ and oxygen saturation of the umbilical artery and an increased $\mathrm{A}-\mathrm{V}$ difference of the same values. If the blood flow of the umbilical artery is also reduced the fetus is unable to exchange its $\mathrm{CO}_{2}$ adequately. This causes a higher $\mathrm{pCO}_{2}$ (and a slightly lower $\mathrm{pH}$ ) of the umbilical artery and a higher $\mathrm{A}-\mathrm{V}$ difference of the same values. If the oxygen supply to fetal tissues is compromised a metabolic acidosis develops. This results in a lower $\mathrm{pH}$, base excess, and standard bicarbonate in the umbilical artery and/or an increased $\mathrm{A}-\mathrm{V}$ difference of the same values.

The lower tpH during the last 30 minutes of labor of the two fetuses with tight cord loop(s) was influenced by cord compression, whereas the other cases of cord complications did not show any difference in comparison with the cases without cord complications.
The APGAR scores of the infants (Tab. II) were not influenced by cord complications even if the cord was tight (four cases).

The slightly increased $\mathrm{A}-\mathrm{V}$ difference of $\mathrm{pCO}_{2}$ (Tab. III) most likely can be explained as an occasional finding (as 18 tests were performed one would expect one of them to be positive, if a five per cent significance level is used) especially as neither the oxygenation state nor the $\mathrm{pCO}_{2}$ of the umbilical artery was influenced by cord complications. In the three cases of tight cord loop(s) in which blood samples from the umbilical vessels could be obtained the increased $\mathrm{A}-\mathrm{V}$ difference of $\mathrm{pH}, \mathrm{pCO}_{2}$, and base excess is in accordance with the pathophysiology of cord compression except for the fact that $\mathrm{pO}_{2}$ and oxygen saturation is not influenced, possibly because of a terminal improvement of the oxygen supply to the fetus at the time of delivery.

The $\mathrm{pO}_{2}$ level at delivery is in accordance with that found by others, e.g. LiN et al. [10] who found an umbilical artery $\mathrm{pO}_{2}$ of $17.9 \pm 5.8 \mathrm{~mm}$ $\mathrm{Hg}(=2.4 \pm 0.8 \mathrm{kPa})$ and an umbilical vein $\mathrm{pO}_{2}$ of $29.0 \pm 6.5 \mathrm{~mm} \mathrm{Hg}(=3.9 \pm 0.9 \mathrm{kPa})$ in normal growth infants without fetal heart rate decelerations.

The higher rate of obstetrical intervention for suspected fetal distress in case of cord complication (vacuum extraction/low forceps: 22 versus 
10\%; Caesarean section: 7 versus $4 \%$ ) can be explained by the pathological CTG (variable decelerations) often associated with cord complications [6, $7,11,12]$.

BRUCE et al. [2] defined cord complications as visually identified loop or loops around the neck or body or as a prolapsed cord. It was concluded that cord complications played a major role in perinatal mortality and morbidity but the occurence of cord complications never exceeded 20 per cent of the total number of risk factors. Although the present material did not include prolapsed cords this situation is only present in about $0.4 \%$ of all deliveries [4] compared to other cord complications being present in about $30 \%$ of all deliveries.

Variable decelerations of the fetal heart rate (FHR) are associated with cord complications $[6,7,8,9$, $11,12]$. Among fetuses with cord complications the incidence of variable decelerations varies from $100 \%[6,11]$ through $89 \%$ [12] to $82 \%$ [7], but fetuses with variable decelerations of the FHR does not neccessarily have cord problems. Thus, the incidence of cord problems in case of variable de- celerations varies fom $82 \%$ [6] through $52 \%$ [12] and $45 \%$ [11] to only $27 \%$ [7]. Consequently, an association between variable decelerations and neonatal depression as found by CiBILS [3] and O'GuREC et al. [11] does not prove that the association is caused by umbilical cord compression, and no major materials have yet been used for investigating the effect of cord complication(s) per se on the neonatal conditions if the fetus has been monitored by CTG.

Our incidence of cord complication(s) is close to that found by others (e.g. GolDKRAND and SPEICHINGER [7]: 28\%; O'GUREC et al. [11]: 34\%).

Although our material is relatively small, our findings do not support the theory that cord complications (other than prolapsed cords) are a major cause of fetal asphyxia. On the contrary, cord complications are common but rarely lead to cord compression which may lead to fetal asphyxia. If labour is monitored with cardiotocography, perinatal outcome in fetuses with cord complication(s) should be very close to that of fetuses without cord complication.

\section{Summary}

Continuous monitoring of fetal scalp tissue $\mathrm{pH}(\mathrm{tpH})$, acid base and oxygenation measurements of the blood of the umbilical artery and vein, and APGAR scoring was performed in 152 deliveries. The effect of cord complication on tpH $(120,90,60,30,15,10,5$, and 0 minutes before delivery), the status of the umbilical artery and vein ( $\mathrm{pH}$, $\mathrm{pCO}_{2}$, base excess, standard bicarbonate, $\mathrm{pO}_{2}$, and oxygen saturation), and the APGAR scores (one and five minutes after delivery) were investigated. Thirty-two per cent of the deliveries were associated with one or more cord complication(s). Cord complications in general did not influence the APGAR scores, the acid base state, or the oxygenation of the fetus and newborn. In the very few cases of tight cord complication(s) tpH showed a marked decrease during the last $\mathbf{3 0}$ minutes of labour, the umbilical blood was slightly acidotic, but the APGAR scores were normal $(8-10$ one and five minutes after delivery). No cases of prolapse of the cord were found. Cord complications are very common but in most cases completely harmless.

Keywords: Continuous fetal pH monitoring, fetal monitoring, intrapartum management, perinatal morbidity, umbilical cord complications.

\section{Zusammenfassung}

Der Einfluß von Nabelschnurkomplikationen auf den fetalen pH, neonatalen APGAR-Score, Säure-Basen-Status und die Oxigenierung des Nabelarterien- und -venenblutes. Bei 152 Entbindungen wurden kontinuierlich der pH-Wert im Kopfschwarten-Fetalblut sowie Säure-Basen-Status und weitere Parameter für die Oxigenierung im Nabel- arterien- und -venenblut gemessen. Anschließend wurde bei den Kindern der APGAR-Score bestimmt. Wir untersuchten den Einfluß von Nabelschnurumschlingungen auf den fetalen $\mathrm{pH} \mathrm{zu}$ verschiedenen Zeitpunkten $(120,90$, $60,30,15,10,5$ und 0 Minuten vor der Geburt) und bestimmten im Umbilikarterien- und -venenblut $\mathrm{pH}, \mathrm{pCO}_{2}$, 
Base-Excess, Standardbikarbonat, $\mathrm{pO}_{2}$ und Sauerstoffsättigung. Der APGAR-Score wurde $1 \mathrm{~min}$ and $5 \mathrm{~min}$ p.p. bestimmt. In unserem Kollektiv waren $32 \%$ der Geburten mit einer oder mehreren Nabenschnurumschlingungen assoziiert. Im allgemeinen beeinflussen Nabelschnurkomplikationen den APGAR-Score sowie den Säure-BasenStatus und die Sauerstoffversorgung des Feten bzw. Neugeborenen nicht. In ganz wenigen Fällen führten schwere Nabelschnurkomplikationen zu einem deutlichen Abfall des pH im fetalen Kopfschwartenblut während der letzten $30 \mathrm{~min}$ vor :der Geburt. Das Nabelblut war geringfügig azidotisch, aber der APGAR-Score normal (8-10 Punkte eine bzw. fün Minuten p.p.). Wir fanden keinen Nabelschnurvorfall. Zusammenfassend läßt sich sagen, daß Nabelschnurkomplikationen häufig vorkommen, in den meisten Fällen aber völlig ungefährlich sind.

Schlüsselwörter: Fetales Monitoring, Geburtsleitung, kontinuierliche fetale pH-Messung, Nabelschnurkomplikationen, perinatale Morbidität.

\begin{abstract}
Résumé
Influence des complications funiculaires sur le $\mathrm{pH}$ foetal le score d'APGAR, l'équilibre acido-basique et l'oxygenation de l'artère et de la veine ombilicale.

L'enregistrement continu du $\mathrm{pH}$ tissulaire au scalp foetal (pHt), les mesures de l'équilibre acido-basique et l'oxygénation du sang ombilical artérial et veineux ainsi que la détermination du score d'APGAR ont été réalisés lors de 152 accouchements. Le retentissement des complications funiculaires sur le pHt $(120,90,60,30,15,10,5$ et 0 minutes avant l'accouchement), sur les constantes du sang ombilical artérial et veineux $\left(\mathrm{pH}, \mathrm{pCO}_{2}\right.$, base excess, bicarbonates, $\mathrm{pO}_{2}$ et saturation en oxygène), et sur les scores d'APGAR (à 1 et à 5 minutes) à été déterminé.
\end{abstract}

Trente deux pour cent des accouchements se sont accompagnés d'une ou plusieurs complications funiculaires. En règle générale, les complications funiculaires n'ont pas eu de retentissement sur les scores d'APGAR, l'équilibre acido-basique ni sur l'oxygénation du foetus et du nouveau-né. Dans les cas très peu nombreux de complications funiculaires serrés, le pHt a montré une diminution importante pendant les 30 dernières minutes du travial, le sang ombilical fut légèrement acidosiquè, mais les $\cdot$ scores d'APGAR restèrent normaux (entre 8 et 10 à 1 et à 5 minutes). Il n'y eu pas de cas de procidence du cordon. Les complications funiculaires sont très courantes, mais dans la plupart des cas elles sont totalement inoffensives.

Mots-clés: Complications funiculaires, conduite à tenir pendant le travail, enregistrement continu du pH foetal, morbidité ṕerinatale, surveillance foetale.

\section{Bibliography}

[1] BOCK, J. E., J. WIESE: Prolapse of the umbilical cord. Acta Obstet. Gynec. Scand. 51 (1972) 303

[2] BRUCE, S., L. S. JAMES, E. BOWE, H. REY, H. SHAMSI: Umbilical cord complications as a cause of perinatal morbidity and mortality. J. Perinat. Med. 6 (1978) 89

[3] CIBILS, L. A.: Clinical significance of fetal heart rate patterns during labor. V. Variable decelerations. Amer. J. Obstet. Gynec. 132 (1978) 791

[4] CUShner, I. N.: Prolapse of the umbilical cord, including a late follow-up of fetal survivors. Amer. J. Obstet. Gynec. 81 (1961) 666

[5] EDITORIAL: Reappraisal of fetal heart rate patterns. J. Perinat. Med. 6 (1978) 65

[6] GABERT, H. A., M. A. STENCHEVER: The results of a five-year study of continuous fetal monitoring on an obstetric service. Obstet. and Gynec. 50 (1977) 275

[7] GOLDKRAND, J. W., J. P. SPEICHINGER: "Mixed cord compression", fetal heart rate pattern, and its relation to abnormal cord position. Amer. J. Obstet. Gynec. 122 (1975) 144

[8] GoOdLIN, R. C., E. W. LOWE: A functional umbilical cord occlusion heart rate pattern. The significance of overshoot. Obstet. and Gynec. 43 (1974) 22
[9] HON, E. H.: Electronic evaluation of the fetal heart rate. VI. Fetal distress - a working hypothesis. Amer. J. Obstet. Gynec. 83 (1962) 333

[10] LIN, C.-C., A. H. MOAWAD, P. J. RosenOW, P. RIVER: Acid-base characteristics of fetuses with intrauterine growth retardation during labor and delivery. Amer. J. Obstet. Gynec. 137 (1980) 553

[11] O'GURECK, J. E., J. F. ROUX, M. R. NEUMAN: Neonatal depression and fetal heart rate patterns during labor. Obstet. and Gynec. 40 (1972) 347

[12] TEJANI, N. A., L. I. MANN, M. SANGHAVI, A. BHAKTHAVATHSALAN, R. R. WEIS: The association of umbilical cord complication and variable decelerations with acid-base findings. Obstet. and Gynec. 49 (1977) 159

[13] WEBER, T.: Continuous scalp tissue pH monitoring during labor. An analysis of 152 consecutive cases. Acta Obstet. Gynec. 59 (1980) 217

[14] WEBER, T., S. HAHN-PEDERSEN, J. E. BOCK: Continuous fetal tissue $\mathrm{pH}$ recordings during labour. Brit. J. Obstet. Gynec. 85 (1978) 770

Received August 28, 1980. Revised February 6, 1981. Accepted March 23, 1981.

Tom Weber, M.D. Skraaplanet 22 DK-2750 Ballerup Denmark 